\title{
Penerapan Model Inkuiri Terbimbing untuk Meningkatkan Hasil Belajar IPA pada Peserta Didik di Sekolah Dasar
}

\section{Wahyu Retnoningsih}

Universitas Sebelas Maret

wahyu.retnoningsih@student.uns.ac.id

\section{Article History}

received 30/4/2021

\begin{abstract}
This reaserch aimed to describe the steps of applying the guided inquiry model to improve science learning outcomes in third grade students. This research is a Classroom Action Research. The data used were qualitative data about information on the application of the steps of the guided inquiry model and quantitative data about science learning outcomes for food technology development materials. Data collection techniques used observation, interviews, and tests. The results showed that the average percentage of students' science learning outcomes was $75.5 \%$ in the first cycle and $86.54 \%$ in the second cycle after learning was carried out by applying the guided inquiry model in 5 steps, namely: (1) orientation; (2) conceptualization); (3) investigation; (4) conclusion; (5) discussion. The conclusion of this research was that the application of the guided inquiry model could improve science learning outcomes for elementary school students.

Keywords: Guided inquiry, learning outcomes, natural science
\end{abstract}

\section{Abstrak}

Penelitian ini bertujuan mendeskripsikan langkah-langkah penerapan model inkuiri terbimbing untuk meningkatkan hasil belajar IPA pada peserta didik kelas III. Penelitian ini merupakan Penelitian Tindakan Kelas. Data yang digunakan yaitu data kualitatif tentang informasi penerapan langkah-langkah model inkuiri terbimbing dan data kuantitatif tentang hasil belajar IPA materi perkembangan teknologi pangan. Teknik pengumpulan data menggunakan observasi, wawancara, dan tes. Hasil penelitian menunjukkan bahwa persentase rata-rata ketuntasan hasil belajar IPA peserta didik sebesar $75,5 \%$ pada siklus I dan $86,54 \%$ pada siklus II setelah dilaksanakan pembelajaran dengan menerapkan model inkuiri terbimbing dalam 5 langkah yaitu: (1) orientation; (2) conceptualization); (3) investigation; (4) conclusion; (5) discussion. Simpulan penelitian ini yaitu penerapan model inkuiri terbimbing dapat meningkatkan hasil belajar IPA pada peserta didik di sekolah dasar.

Kata kunci: Inkuiri terbimbing, Hasil belajar, IPA 


\section{PENDAHULUAN}

Saat ini, berbagai negara di dunia sedang mengalami pandemi covid-19. Di Indonesia, kasus terkonfirmasi covid-19 pertama kali diumumkan oleh Menteri Kesehatan pada tanggal 02 Maret 2020. Berbagai cara telah dikampanyekan untuk memutus mata rantai penyebaran covid-19, salah satunya adalah dengan menghindari kerumunan. Hal tersebut memberikan dampak bagi dunia pendidikan sehingg proses belajar mengajar harus dilaksanakan secara daring dari rumah. Meskipun dalam masa pandemi, fungsi pendidikan harus berjalan sesuai UndangUndang Sistem Pendidikan Nasional Nomor 20 Tahun 2003. Fungsi pendidikan dalam Undang-Undang tersebut yaitu mengembangkan potensi dan membentuk watak peserta didik agar mampu menjadi bangsa yang bermartabat.

Sistem pendidikan abad-21 telah mengalami berbagai perubahan dari abad sebelumnya. Hal tersebut menuntut bangsa Indonesia untuk menyesuaikan diri dan mengasah kemampuan dalam menghadapi berbagai tuntutan dan perubahan (Komara, 2018: 19). Sistem pendidikan abad-21 melatih peserta didik untuk mengembangkan empat keterampilan yang sering dikenal dengan 4C yaitu collaborative, creative and innovative, critical thinkink and problem solving, dan communication. Guru dapat mengembangkan berbagai keterampilan tersebut apabila guru mampu mengembangkan kegiatan yang menantang peserta didik untuk berpikir kritis dalam memecahkan masalah (Septikasari \& Rendy, 2018: 108).

Proses pembelajaran sesuai kurikulum 2013 menggunakan pendekatan tematikterpadu dengan karakteristik antara lain: (1) berpusat pada peserta didik, (2) memberikan pengalaman langsung yang nyata, dan (3) berkaitan dengan lingkungan sekitar peserta didik (Akbar, 2016: 19). Dalam pembelajaran tematik-terpadu, materi IImu Pengetahuan Alam (IPA) di kelas I-III terintegrasi pada muatan pelajaran Bahasa Indonesia sedangkan pada kelas IV-VI berdiri sendiri.

Kegiatan-kegiatan IPA dalam pembelajaran mampu memberikan kesempatan kepada peserta didik untuk mendapatkan pengalaman pada pembelajaran melalui observasi terhadap fenomena alam, eksperimen, dan diskusi (Sayekti, 2015:40). Disamping itu, selain mengembangkan keterampilan proses untuk menyelidiki masyarakat sekitar, IPA dalam pembelajaran juga memiliki tujuan untuk mengembangkan kemampuan memecahkan masalah dan membuat keputusan (Sulthon, 2016: 50). Setelah belajar IPA, peserta didik memperoleh hasil belajar yaitu kemampuan-kemampuan yang diperoleh akibat peserta didik belajar IPA sehingga mereka mampu mengembangkan berbagai pengetahuan, pemahaman dan kemampuan analisisnya terhadap lingkungan alam yang ada di sekitar.

Berdasarkan hasil observasi yang dilaksanakan oleh peneliti pada tanggal 11 Januari 2021 di SDN 5 Kebumen terhadap proses pembelajaran daring selama masa pandemi, ditemukan fakta: (1) metode pembelajaran yang digunakan adalah penugasan melalui Whatsapp Group sehingga kurang variatif, (2) peserta didik belum berpartisipasi aktif secara optimal dalam pembelajaran karena belum menggunakan model pembelajaran berbasis penemuan. (3) peserta didik cenderung pasif dalam mengajukan pertanyaan maupun mengemukakan gagasan, (4) hasil belajar IPA peserta didik kelas III masih tergolong rendah.

Berdasarkan nilai evaluasi IPA materi teknologi produksi pangan, dari jumlah total peserta didik kelas III sebanyak 26 orang dengan KKM (Kriteria Ketuntasan Minimal) 68, ada 15 peserta didik yang mendapatkan nilai di bawah KKM dan 11 peserta didik mendapatkan nilai di atas KKM. Itu berarti ada 57,69\% peserta didik yang belum mencapai KKM dan 42,31\% peserta didik yang sudah mencapai KKM.

Berdasarkan uraian yang dijelaskan di atas, dapat diindikasi bahwa hasil belajar peserta didik belum optimal. Perlu dilakukan perbaikan pada kegiatan pembelajaran dengan penerapan suatu model pembelajaran yang berpusat pada peserta didik dan merangsang keaktivannya dalam kegiatan pembelajaran. Salah satu model yang dapat 
diterapkan adalah model inkuiri terbimbing. Anam (2016: 17) menjelaskan bahwa inkuiri terbimbing adalah suatu kegiatan yang dapat membuat peserta didik bekerja, menemukan jawaban dari permasalahan yang diberikan dengan bimbingan yang intensif dari guru. Adapun langkah-langkah dalam kegiatan pembelajaran dengan menerapkan model inkuiri terbimbing seperti yang dikemukakan oleh Pedaste, et al. (2015: 48) yaitu: 1) orientation (mengenalkan masalah), 2) conceptualization (mengkonseptualisasi), 3) investigation (menyelidiki), 4) conclusion (menyimpulkan), 5) discussion (mendiskusikan).

Berdasarkan penelitian yang dilakukan oleh Aribawati, Firosalia, dan Indri (2018) yang berjudul "Penerapan Model Pembelajaran Inkuiri Terbimbing untuk Meningkatkan Kreativitas dan Hasil Belajar IPA Siswa Kelas 3 SD" menyatakan bahwa model inkuiri terbimbing dapat meningkatkan kreativitas dan hasil belajar peserta didik kelas 3 SD. Model inkuiri terbimbing memiliki kelebihan bahwa pengetahuan yang diperoleh oleh peserta didik bersifat penyelidikan karena diperoleh dari proses penemuan dan dapat memperpanjang ingatan terhadap pengetahuan peserta didik karena pengetahuan tersebut didapatkan melalui hasil pemikiran sendiri (Winanto dan Darma, 2016: 124). Selain itu, model inkuiri terbimbing juga memiliki kelebihan dapat mengembangakan aspek kognitif peserta didik (Shoimin, 2016: 86). Diharapkan dengan penerapan model inkuiri terbimbing, hasil belajar IPA peserta didik dapat meningkat.

Berdasarkan uraian di atas, untuk meningkatkan hasil belajar IPA pada materi perkembangan teknologi pangan di kelas III, peneliti berencana melakukan penelitian tindakan kelas dengan judul "Penerapan Model Inkuiri Terbimbing untuk Meningkatkan Hasil Belajar IPA pada Peserta Didik di Sekolah Dasar". Adapun rumusan masalah dari penelitian ini yaitu: (1) Bagaimana langkah-langkah penerapan model inkuiri terbimbing untuk meningkatkan hasil belajar IPA pada peserta didik di sekolah dasar? (2) Apakah penerapan model inkuiri terbimbing dapat meningkatkan hasil belajar IPA pada peserta didik di sekolah dasar? Penelitian ini bertujuan untuk: (1) mendeskripsikan langkahlangkah penerapan model inkuiri terbimbing untuk meningkatkan hasil belajar IPA pada peserta didik di sekolah dasar, dan (2) meningkatkan hasil belajar IPA pada peserta didik di sekolah dasar.

\section{METODE}

Penelitian ini merupakan penelitian tindakan kelas yang dilaksanakan dalam 2 siklus sebanyak 4 pertemuan. Prosedur penelitian menggunakan modifikasi dari Arikunto (2013: 138-140) yang terdiri dari: (1) perencanaan, (2) pelaksanaan tindakan, (3) pengamatan, dan (4) refleksi. Penelitian ini dilaksanakan dari bulan Februari hingga Juni 2021. Subjek dalam penelitian ini yaitu peserta didik kelas III SDN 5 Kebumen tahun ajaran 2020/2021 yang berjumlah 26 peserta didik dengan rincian 9 peserta didik laki-laki dan 17 peserta didik perempuan. Data yang digunakan yaitu data kuantitatif tentang nilai hasil evaluasi peserta didik dan data kualitatif tentang informasi penerapan langkah-langkah model inkuiri terbimbing. Teknik dan alat pengumpulan data yang digunakan antara lain observasi menggunakan lembar observasi, wawancara menggunakan pedoman wawancara, dan tes menggunakan lembar soal evaluasi. Data kuantitatif dianalisis menggunakan statistik deskriptif, dan data kualitatif dianalisis menggunakan teknik analisis data menurut Miles dan Huberman (Sugiyono, 2012: 247-253) dengan tahapan: (1) data reduction, (2) data display, dan (3) conclusion drawing/verivication. Indikator kinerja dalam penelitian ini adalah $85 \%$ untuk penerapan pangkah-langkah model inkuiri terbimbing dan $85 \%$ untuk ketuntasan minimal siswa.

\section{HASIL DAN PEMBAHASAN}

Penerapan model inkiri terbimbing untuk meningkatkan hasil belajar peserta didik di sekolah dasar dilaksanakan dalam dua siklus. Setiap siklus terdiri dari empat 
tahapan, yaitu tahap perencanaan, pelaksanaan tindakan, pengamatan dan refleksi. Setiap siklus terdiri dari dua pertemuan dengan alokasi waktu 70 menit untuk setiap pertemuan.

Proses pembelajaran menggunakan model inkuiri terbimbing diterapkan menggunakan langkah-langkah: 1) orientation (mengenalkan masalah), 2) conceptualization (mengkonseptualisasi), 3) investigation (menyelidiki), 4) conclusion (menyimpulkan), 5) discussion (mendiskusikan). Langkah-langkah model inkuiri terbimbing tersebut mengacu pada langkah-langkah yang dikemukakan oleh Pedaste, et al. (2015: 48) dan Sanjaya (2012: 201-205) yang peneliti simpulkan sehingga menjadi langkah-langkah tersebut. Hasil observasi penerapan model inkuiri terbimbing mengalami peningkatan pada setiap siklusnya hingga mencapai indicator kinerja penelitian yang telah ditargetkan yaitu sebesar $85 \%$. Peningkatan hasil observasi penerapan model inkuiri terbimbing terhadap guru dan peserta didik siklus I dan II dapat dilihat pada tabel 1 berikut.

Tabel 1. Persentase Hasil Observasi Penerapan Model Inkuiri Terbimbing terhadap Guru dan Peserta Didik Siklus I dan II

\begin{tabular}{lcc}
\hline & Siklus I (\%) & Siklus II (\%) \\
\hline Guru & 81.46 & 93.96 \\
Peserta didik & 74.09 & 87.20 \\
\hline
\end{tabular}

Berdasarkan tabel 1 di atas, persentase hasil observasi penerapan model inkuiri terbimbing terhadap guru mengalami peningkatan sebesar $12.5 \%$ dari hasil pada siklus I yaitu $81.46 \%$ meningkat ke hasil pada siklus II yaitu $93.96 \%$. Ppersentase hasil observasi penerapan model inkuiri terbimbing terhadap peserta didik juga mengalami peningkatan sebesar $13.11 \%$ dari hasil pada siklus I yaitu $74.09 \%$ meningkat ke hasil pada siklus II yaitu $87.20 \%$. Dari uraian tentang pesertase hasil observasi penerapan model inkuiri terbimbing terhadap guru dan peserta didik dapat disimpulkan bahwa dari siklus I ke siklus II telah mengalami peningkatan dan sudah mencapai target indikator kinerja penelitian sebesar $85 \%$.

Pada langkah pertama yaitu orientation (menenalkan masalah), guru menyajikan permasalah menggunakan gambar yang berkaitan dengan materi perkembangan teknologi pangan yang ada di kehidupan sehari-hari. Penyajian masalah menggunakan gambar yang sesuai dengan kehidupan situasi nyata dan lingkungan peserta didik dapat membuatnya lebih tertarik dan mudah dalam mengamati permasalahan yang disajikan (Erowati, 2015: 288).

Pada langkah kedua yaitu conceptualization (mengkonseptualisasi), guru bertanya jawab dan berdiskusi untuk menggali pengetahuan peserta didik terhadap masalah. Guru meminta peserta didik membaca pertanyaan dan menyaksikan video yang berkaitan dengan masalah. Kemudian, peserta didik diminta untuk mencari informasi dari video tersebut. Penggunaan pertanyaan-pertanyaan yang dibuat oleh guru dapat mengontrol jawaban peserta didik agar tetap fokus terhadap masalah sesuai dengan tujuan yang ditetapkan (Samatowa, 2016: 65)

Pada langkah ketiga yaitu investigation (menyelidiki), peserta didik diminta untuk menyiapkan alat dan bahan yang diperlukan, dibimbing untuk melakukan percobaan, menuliskan hasil percobaan dan menganalisisnya. Dari kegiatan tersebut, sesuai dengan pendapat Putri, Indrawati, dan Mahardika, (2016: 323) bahwa di dalam model inkuiri terbimbing, peserta didik dibimbing oleh guru untuk mengumpulkan dan menganalisis data yang nantinya berguna untuk membuktikan hipotesis yang telah dibuatnya.

Pada langkah ke empat yaitu conclusion (menarik simpulan), peserta didik mengubah hasil percobaan ke dalam bentuk kalimat deskripsi sehingga peserta didik 
mudah untuk memahami hasil percobaan sebagai bekal membuat simpulan. Pembuatan simpulan juga semakin terarah karena guru memberikan kata kunci sesuai dengan pertanyaan pengarah yang digunakan sebagai hipotesis awal. Pemberian pengarahan dapat memaksimalkan kemampuan peserta didik dalam menarik simpulan (Rahmawaty, Nurhayati, dan Muhammad, 2020: 35).

Pada langkah kelima yaitu discussion (mendiskusikan hasil), peserta didik diminta untuk menyamakan hasil percobaan dengan hipotesis yang telah dibuat. Kemudian diminta untuk mengkomunikasikan hasil percobaan dan simpulan yang diperoleh melalui video. Mengkomunikasikan hasil penelitian menggunakan video dapat melatih rasa percaya diri dan keberanian peserta didik. Karena peserta didik yang kurang percaya diri biasanya kurang mampu menyampaikan pesan (Aristiani, 2016: 185)

Selain peningkatan hasil observasi penerapan model inkuiri terbimbing, data hasil evaluasi yang dilakukan di akhir pembelajaran pada setiap pertemuan dapat dilihat pada tabel 2 berikut.

Tabel 2. Persentase Ketuntasan Peserta Didik pada siklus I dan II

\begin{tabular}{ccccc}
\hline No. & Siklus & \multicolumn{2}{c}{ Tuntas (\%) } & Rata- \\
\cline { 3 - 4 } & & Pertemuan 1 & Pertemuan 2 & rata \\
\hline 1 & I & 74.08 & 76.92 & 75.5 \\
2 & II & 84.62 & 88.46 & 86.54 \\
\hline
\end{tabular}

Berdasarkan tabel 2 di atas, dapat diketahui bahwa rata-rata ketuntasan belajar peserta didik pada siklus I dan siklus II mengalami peningkatan sebesar $11.04 \%$ dari persentase rata-rata ketuntasan pada siklus I yaitu $75.5 \%$ ke rata-rata ketuntasan pada siklus II yaitu $86.54 \%$. Rata-rata ketuntasan pada siklus II sebesar $86.54 \%$ sudah mencapai target indicator kinerja penelitian yaitu $85 \%$.

Berdasarkan hasil penelitian di atas, dapat diketahui bahwa penerapan model pembelajaran inkuiri terbimbing dapat meningkatkan hasil belajar peserta didik di sekolah dasar dilihat dari persentase ketercapaian hasil pada siklus I dan siklus II. Adanya peningkatan hasil belajar IPA dengan menerapkan model inkuiri terbimbing sesuai dengan penelitian yang dilakukan oleh Aribawati, Firosalia, dan Indri (2018) yang menyatakan bahwa model inkuiri terbimbing dapat meningkatkan kreativitas dan hasil belajar peserta didik kelas 3 SD. Selain itu, penelitian serupa juga dilakukan oleh Rosita dan teman-temannya pada tahun 2016 yang menunjukkan hasil bahwa hasil belajar peserta didik di SD Inpres 3 Terpencil Baina'a meningkat melalui penerapan model inkuiri terbimbing.

\section{SIMPULAN}

Berdasarkan penelitian hasil dan pembahasan, simpulan dari penelitian ini yaitu langkah-langkah model inkuiri terbimbing untuk meningkatkan hasil nelajar IPA peserta didik di sekolah dasar yang diterapkan yaitu: (1) orientation (mengenalkan masalah), (2) conceptualization (mengkonseptualisasi), (3) investigation (menyelidiki), (4) conclusion (menyimpulkan), (5) discussion (mendiskusikan).

Model pembelajaran inkuiri terbimbing dapat meningkatkan hasil belajar IPA pada peserta didik di sekolah dasar. Hasil tersebut dibuktikan dengan rata-rata ketuntasan belajar peserta didik pada siklus I dan siklus II mengalami peningkatan sebesar $11.04 \%$ dari persentase rata-rata ketuntasan pada siklus I yaitu $75.5 \%$ ke ratarata ketuntasan pada siklus II yaitu $86.54 \%$ dan rata-rata ketuntasan pada siklus II sudah mencapai target indikator kinerja penelitian yaitu $85 \%$.

Berdasarkan simpulan di atas, penelitian tentang penerapan model inkuiri terbimbing untuk meningkatkan hasil belajar IPA pada peserta didik di sekolah dasar 
yang telah dilakukan dapat dijadikan acuan dan referensi untuk dapat mempersiapkan diri dan materi bagi penelitian selanjutnya.

\section{DAFTAR PUSTAKA}

Akbar, S., dkk. (2016). Implementasi Pembelajaran Tematik di Sekolah Dasar. Bandung: Rosadakarya Offset.

Anam, K. (2016). Pembelajaran Berbasis Inkuiri Terbimbing: Metode dan Aplikasi. Yogyakarta: Pustaka Pelajar.

Aribawati, D., Firosalia, K., \& Indri, A. (2018). Jurnal Sains dan Teknologi ISSN 2620-5475 (Online) Penerapan Model Pembelajaran Inkuiri Terbimbing untuk Meningkatkan Kreativitas dan Hasil Belajar IPA Siswa Kelas 3 SD. Jurnal Sains dan Teknologi, 1 (1), 70-75.

Arikunto, S. (2013). Prosedur Penelitian: Suatu Pendekatan Praktik. Jakarta: Rineka Cipta.

Arisanti, R. (2016). Meningkatkan Percaya Diri Siswa melalui Layanan Informasi Berbantuan Audiovisual. Jurnal Konseling GUSJIGANG, 2 (2), 183-189.

Erowati, M., T. (2015). Pengaruh Penggunaan Media Benda Konkret terhadap Hasil Belajar IPA Siswa Kelas IV di SDN Sumberejo 01. Prosiding Seminar Nasional Pendidikan "Meretas Sukses Publikasi IImiah Bidang Pendidikan Jurnal Bereputasi”, hIm 288-296, Universitas Sebelas Maret Surakarta dan ISPI Wilayah Jawa Tengah, Surakarta.

Komara, E. (2018). Penguatan Pendidikan Karakter dan Pembelajaran Abad 21. SIPATAHOENAN: Shout-East Asian Journal for Youth, Sports \& Healt Education, 4 (1), 17-26.

Pedaste, M., et. al. (2015). Phases of Inquiry-based Learning: Definitions and the Inquiry Cycle. Journal Educational Research Review, 14, 47-61.

Presiden Republik Indonesia. (2003). Undang-Undang Sistem Pendidikan Nasional Nomor 20 tahun 2003. Jakarta: Sekertariat Negara.

Putri, H., K., Indrawati, Mahardika, I., K. (2016). Model Pembelajaran Inkuiri Terbimbing disertai Teknik Peta Konsep dalam Pembelajaran Fisika di SMA. Jurnal Pembelajaran Fisika, 4 (4), 321-326.

Rahmawaty, S., Nurhayati, \& Muhammad, A. (2020). Kemampuan Menarik Kesimpulan Peserta Didik yang Menggunakan LKPD Pertanyaan Pengarah Kelas XI MIA 2 SMA Negeri 11 Makassar. Prosiding Seminar Nasional Pendidikan Fisika PPs, hlm 33-36, Universitas Negeri Makasar, Makasar.

Rosita, R., dkk. (2016). Meningkatkan Hasil Belajar Peserta didik pada Mata Pelajaran IPA Melalui Metode Inkuiri Terbimbing di Kelas IV SD Inpres 3 Terpencil Baina'a. Jurnal Kreatif Tadulako Online, 4 (6), 244-254.

Samatowa, U. (2016). Pembelajaran IPA di Sekolah Dasar. Jakarta: Indeks.

Sanjaya, W. (2012). Strategi Pembelajaran Berorientasi Standar Proses Pendidikan. Jakarta: Kencana Prenada media.

Sayekti, I., C. (2015). Science Learning by Using Guided Inquiry Approach Through Experiment and Demonstration Method Viewed from Students' Scientific Attitudes. Proceeding of International Conference on Research, Implementation and Education of Mathematics and Sciences, hlm. 39-46, Universitas Negeri Yogyakarta, Yogyakarta.

Septikasri, R. \& Rendy, N. F. (2018). Keterampilan 4C Abad 21 dalam Pembelajaran Pendidikan Dasar. Jurnal Tarbiyah Al-Awlad, 8 (2), 112-122.

Shoimin, A. (2016). 68 Model Pembelajaran Inovatif dalam Kurikulum 2013. Yogyakarta: Ar-Ruzz Media. 
Volume 9 Nomor 1 Tahun 2021

Sugiyono. (2012). Metode Penelitian Kuantitatif, Kualitatif, dan R\&D. Bandung: Alfabeta.

Sulthon. (2016). Pembelajaran IPA yang Efektif dan Menyenangkan bagi Siswa Madrasah Ibtidaiyah (MI). Elementary: Jurnal IImiah Pendidikan Dasar, 7 (1), 38-54.

Winanto, A., \& Darma, M. (2016). Implementasi Strategi Pembelajaran Inkuiri untuk Meningkatkan Motivasi dan Hasil Belajar IPA Siswa Kelas 5 SD Negeri Kutowinangun 11 Kota Salatiga. Scholaria: Jurnal Pendidikan dan Kebudayaan, 6 (2), 119-138. 